Mme Royal: I will pay particular attention to guaranteeing that the storage of nuclear waste is reversible. Parliament will decide in ten years time which options should be retained for long-term management of nuclear waste.

I think that the current government took the decision to go ahead with the EPR without adequate analysis or debate. No impact assessment was presented to parliament, and no effort was made to create real diversification in our energy mix. We cannot set our country's energy future in stone without an in-depth debate, not just on the EPR but on the entire issue.

M. Bayrou: The EPR project will be maintained. But we need a scientific assessment of it. The renewal of our existing fleet of reactors hinges on this project, and a decision this important for our energy policy cannot be taken on the sly. There must be as wide and democratic a debate as possible.

A demonstration project should be launched rapidly to prove that after temporary storage, the volume and radioactivity of waste can be reduced to low levels. This is necessary to reassure the many men and women in France, and worldwide, who have doubts about this form of energy because of the risks still associated with it.

\section{What are your priorities for space?}

Mme Royal: France is a major space power, having developed, with its European partners, the high-quality Ariane launchers. I think that the high costs of manned space flight mean that such ventures should be carried out in international programmes. The launch of Earthobservation satellites is, of course, a priority.
M. Bayrou: The emphasis should also be on fundamental research and exploration of the Universe, a field in which France and Europe are proficient, and then on GMES and on the Galileo navigation system. For Europe to carry sufficient weight, should it aim for the Moon or even farther, perhaps going it alone? Should it support the International Space Station? This all demands reflection.

M. Sarkozy: The Galileo project has become bogged down in national quarrels that are petty compared with the stakes on the table, and breaking the current deadlock is a matter of urgency.

I'm keen on greater European cooperation in space. France should be ready to make the extra effort to lead the way, if needs be, as it has done in the past. The main goal must be to maintain and reinforce our basic civil, military and scientific skills. If, after that, we can together develop more ambitious manned flight and planetary-exploration missions, then why not?

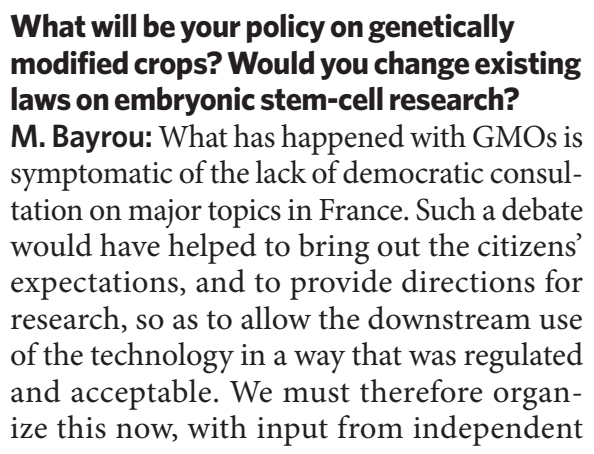

scientists. In the meantime, I am in favour of an immediate moratorium on GMOs.

M. Sarkozy: I want research to continue on GMOs as, among other things, that is the only way to improve our knowledge of the potential risks to human health and biodiversity. Unless we can be highly certain that they are harmless, I am less enthusiastic about their industrialization and marketing.

As for research on embryonic stem cells, with the creation of the Agency of Biomedicine in 2005, researchers can now submit research projects for review. I'm delighted that projects that have been favourably reviewed can thus develop in our country within a clear and evolving framework. I think it's indispensable that research also continues to develop in this area.

Mme Royal: I am in favour of a moratorium on open-field cultivation of GMOs and of having a public debate on this question, which is of interest to all citizens.

Research on human stem cells should be permitted provided that they are obtained after informed consent, they come from embryos that are no longer part of any fertility treatments and the proposed protocol has been rigorously examined. We must revise the legal framework to reconcile ethical principles and scientific progress.

For fuller answers, and for questions on the street protests of 2004, nuclear deterrence, the CNRS, EU science and the common agricultural policy, visit our website at http://tinyurl.com/23fwj5. See also Editorial, page 831.

\title{
Let science speak for itself
}

\section{You've heard what the presidential candidates think the challenges facing science in France are. Nature also canvassed opinion across the French research spectrum: from young researchers to reformers and industrialists. Declan Butler reports.}

\section{Pierre Chambon}

Biologist at the Institute of Genetics and Molecular and Cellular Biology in Illkirch near Strasbourg, of which he was formerly director.

The common assertion that French research is doing badly is untrue; it's doing badly in some sectors, with life sciences the main concern. The French research system hasn't been organized in 40 years. There's duplication in biology across the CNRS, INSERM, INRA and the universities that's damaging competitiveness. We need a single life-sciences agency, plus perhaps a second for more applied work, to bring together the best life scientists and give them the means to do top-quality research.

Biotech companies and universities compete for the best scientists worldwide. But France's civil-service pay scales mean that a biologist earns the same as a sociologist or anthropologist. This makes it impossible to attract the world's best biologists, but life sciences in France cannot survive on French researchers alone.
In France, most scientists start and finish their careers in the same organization, whether this is a research agency or a university. There are two separate corps of scientists, some teaching and researching, some doing only research. This is inefficient, because you want less effective researchers doing more teaching, and the best researchers doing less, according to their success in winning grants. For this to work, we need to have just a single corps of researchers, all attached to universities, with the research agencies transformed into research councils. 

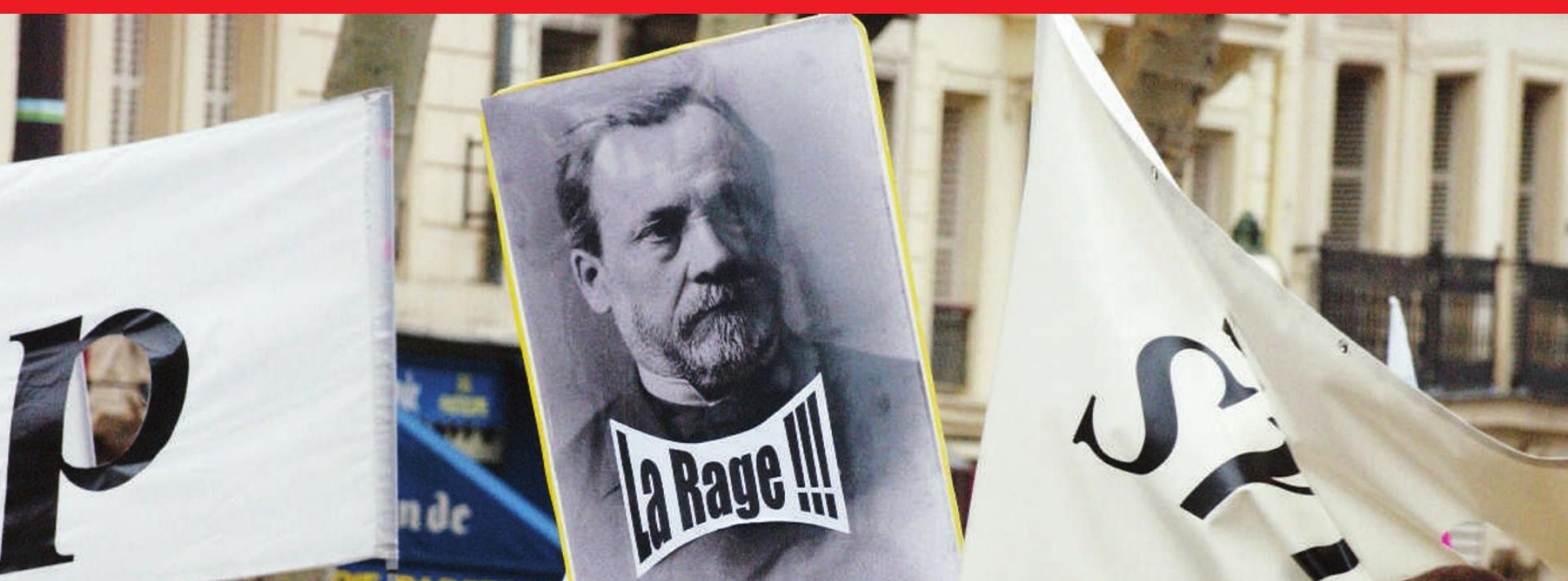

1.
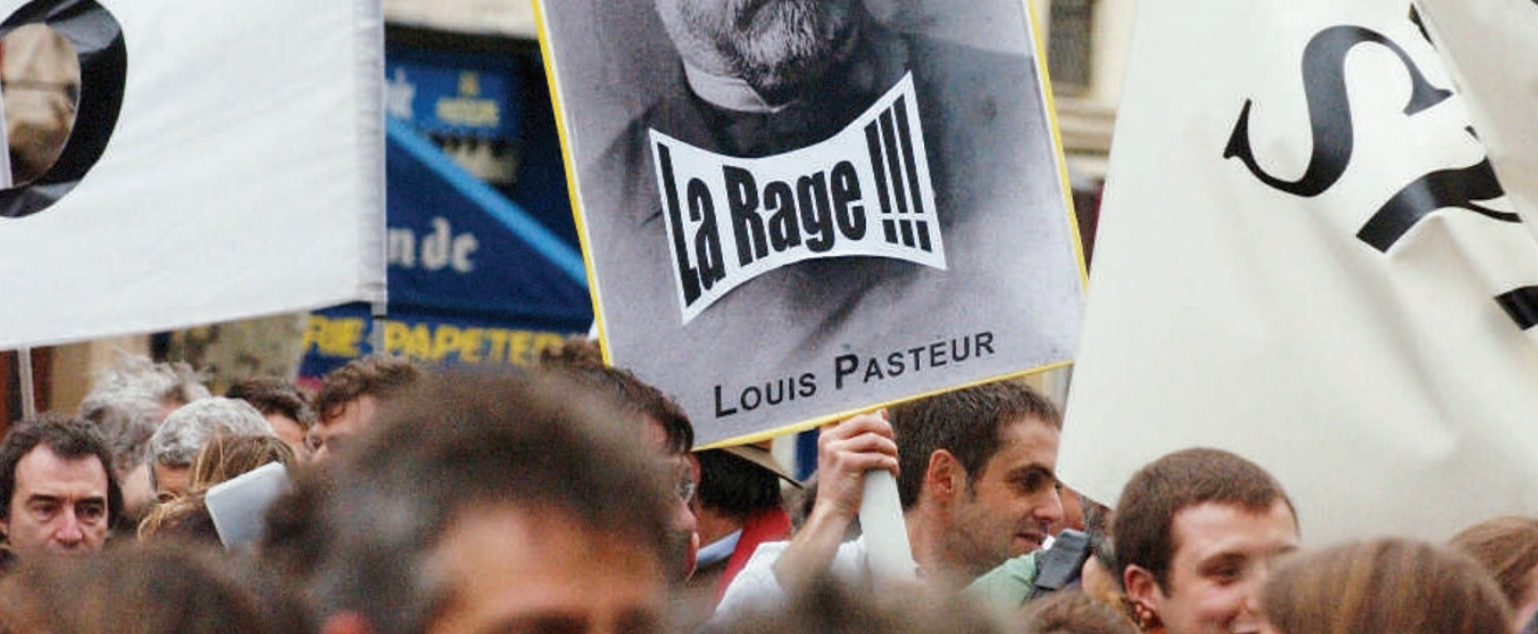

The efficiency of French research won't improve without more flexibility about who gets what during their career. France wants top research but rejects élitism; that's not possible.

Biology also lacks a strong industrial lobby in France to push for greater public support. When the US National Institutes of Health's budget doubled in [the] five years [to 2003], France's was flat. The French drug industry is weak, comprising mainly Sanofi-Aventis [a multinational with much of its research in the United States] and a few other companies.

In Strasbourg, our institute was the first in Europe for molecular geneticists, and in the top 10 worldwide. But soon we will have lost all our top foreign scientists. This is not just because of the salaries; people would prefer to stay in France because of the quality of life. But they feel they are wasting their time having to look

right and left for scraps. They can get better working conditions, and salaries, abroad.

There's no point in creating more posts unless people are given the means to do topquality research, and there's no point in increasing funding if we don't reform our structures, otherwise it is like watering sand. Unless we attack the problems of the research agencies, modernizing French research will be mission impossible. We, the researchers, want reform.

\section{Edouard Brézin}

Physicist at the Ecole Normale Supérieure in Paris and ex-president of CNRS and the French Academy of Sciences.

The low attractiveness of science and engineering careers is a big problem in France. The young are increasingly turning to other careers.

Moreover, the best students aim not to "France has a chronic
problem building links
between public and
private research. In
French industry those
in management rarely
have any research
training."
$\quad$ - Edouard Brézin go to university or to get a $\mathrm{PhD}$, but to graduate as an engineer from the élite Grandes Ecoles, as this offers better career prospects. So although at present French research is strong in many fields, I'm not at all sure that this will still be the case in $10-15$ years time.

The high teaching loads imposed on young scientists start- ing work at a university prevent them from doing research during the very years when they should be cutting their research teeth. They are recruited on the basis of research talents, and we then annihilate their chances of establishing themselves. New recruits need to be freed up for research.

France has a chronic problem building links between public and private research. The concept of wealth creation in public research is perhaps less naturally engrained in our culture than in the United States and Britain. But I'm also struck by the fact that in French industry those in management rarely have any research training, as most are graduates of the Grandes Ecoles. Companies also tend to have a negative view of people with a research background - an engineer from one of the Grandes Ecoles who also has a PhD might be best advised to hide that fact in job interviews.

The relationship of universities to the Grandes Ecoles is one of many important questions facing the university system. There are important issues that need to be tackled to reform university governance, and to give them greater autonomy than they have in today's homogenized national system. But there hasn't been a major reform of French universities for decades, so all of these questions are off the radar.

The new ANR has its pros and cons. It's beneficial in that it makes it easier for young 
research teams to attain funding, but the central government still decides research priorities and nominates management teams. Compare this with how its German counterpart, the DFG, is run; there the management is largely elected by the scientific community on the grounds of their scientific expertise. They are two different worlds.

That said, the French scientific community also needs to reform itself. The research agencies and universities elect various committees and evaluation panels, and I've long fought with the community for people to be elected on merit, and not on trade-union criteria. When I receive a voting bulletin, it doesn't give any indication of whether the candidate has even published in the past 5 years, just their tradeunion profession of faith. It's incredible, ridiculous: a system from the Middle Ages.

\section{Maïwenn Corrignan}

President of the Young Researchers'

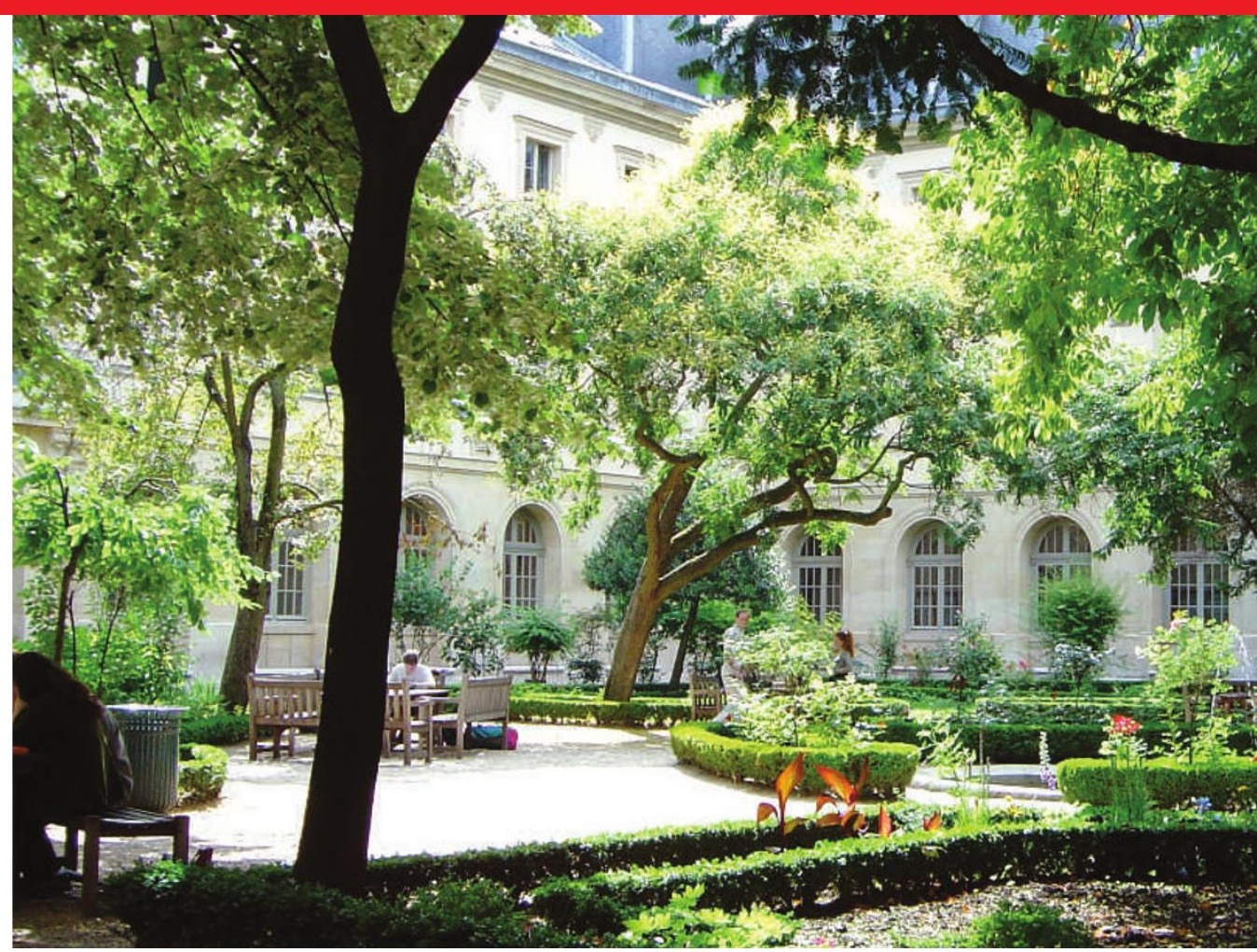

The Grande Ecoles, such as the ENS in Paris, have come to dominate French higher education. Confederation and a sociologist at the University of Rennes 2 in Brittany.

mobility between research agencies, universities and industry.

Better career guidance is also needed, so that the young are aware of oppor"Many scientists would
prefer not to stay at one
research organization
for their entire career,
but there are too
few bridges to allow
greater mobility."
- Maïwenn Corrignan tunities beyond the research agencies and universities, both in industry and outside research. Things are improving; more than $20 \%$ of $\mathrm{PhDs}$ now go into industry, and that trend is increasing. Companies are also beginning to recruit, and value, those with PhDs. The young aren't disinterested in research; it's the poor working conditions that Last year's decree that the $\mathrm{PhD}$ is a professional qualification was a real advance for young scientists here. It put an end to the widespread practice - particularly by research charities - of paying postgrads a minimal salary without benefits (or no salary at all). This change forces research agencies to provide contracts and pay social security and pension benefits, and also means postgrads on short-term contracts subsequently qualify for unemployment benefit.

The financial uncertainty of $\mathrm{PhD}$ students and the lack of recognition of the value of a $\mathrm{PhD}$ in recruitment was one of the main factors behind the street demonstrations of 2004. We don't want a postdoc system. It won't work in France, which has a culture of full-time employment; recruiters have a negative view of scientists with multiple short-term contracts as perpetual students.

We need a change in mentalities. Many scientists would prefer not to stay at one research organization for their entire career, but there are too few bridges to allow greater put them off.

\section{Alain Trautmann}

Cell biologist at the Cochin Institute in Paris and an instigator and former spokesman for the movement 'Save Research' that led protests in 2004.

In 2004, the scientific community in France organized an emergency nationwide science summit, and proposed a rash of reforms. But the government ignored them, and pushed ahead with its own. We are not against reform, but want changes to be decided in consultation with the science community. Successive governments have instead tried to impose unworkable reforms.

The current government is trying to impose an American system on France, without taking our history into account. They act as if the CNRS and the Grandes Ecoles, the main elements of the French system, don't exist. The fact that the Grandes Ecoles divert the brightest young people away from science is cata- strophic. We need to evolve the French system, taking such realities into account.

In 2004 we proposed that, to make science more attractive to the young, the government tie its generous tax relief to companies not just on the basis of their degree of investment in research but also according to the number of trained scientists with $\mathrm{PhDs}$ they recruited. This could create change, and would not cost the state any extra, but the government rejected it. Ideologically, it was opposed by the lobby of the Grandes Ecoles, whose engineering graduates dominate the state apparatus.

The government also wants to make the universities the centrepiece of the research system. But France is currently one of the worst-placed countries in terms of investment in its universities. The universities that perform well are those that have joint laboratories with the CNRS. I'm not for maintaining the CNRS just because it already exists, but it's naive to believe, as some in government do, that one can simply abolish the CNRS overnight. Doing so without first reforming and reinvesting in the universities would just make the system worse.

\section{André Choulika}

Chief executive of Cellectis, a biotech spin-off from the Pasteur Institute in Paris.

France's competitiveness in research and innovation has emerged as an election issue in the 2007 presidential campaign. Significant investment in the life sciences in $2005-€ 2.4$ billion [US $\$ 3.2$ billion], or $25.7 \%$ of the 2005 civil research budget - has so far failed to deliver the anticipated socioeconomic benefits.

The money has not been spent optimally. The multiplication of publicly supported research 


\title{
Let science speak for itself
}

\author{
Additional text for article doi:10.1038/446850a
}

\section{Bertrand Monthubert}

Mathematician at Paul Sabatier University in Toulouse and current president of 'Save Research'.

French researchers keep being told they should adopt an Anglo-Saxon system for research funding, yet if you look at Britain's share of world publications, its drop is, in fact, the same - 13\% from 1999 to 2004 . That said, we are not opposed to funding research on the basis of competitive projects. But we are opposed to the government's eagerness to use project funding for short-term strategic research, while at the same time cutting back on the research agencies that offer labs long-term stable funding.

INSU [the National Institute for Earth Sciences and Astronomy], for example, must plan expensive long-term ocean expeditions, and carry out its own peer review of missions. But current budgetary difficulties mean that it is having problems putting together expeditions for France's contribution to the International Polar Year.

You can't do this sort of research with 3-year project grants. The comparison of the French ANR to the US National Science Foundation [NSF] is inaccurate; the NSF often provides rolling funding for labs, much as the CNRS already does. France's centralized history allows us to carry out evaluations of laboratories at the national scale. The United States created its National Institutes of Health to obtain precisely that sort of overall vision, a common evaluation system. With the ANR, we risk giving labs large sums of money for 3 years, and then nothing more.

We support funding by project for new research areas in which France is lagging. We also support it as a way of bringing together the various research agencies. There are too many research agencies in France, and simplification is long overdue.

Increasingly, it is the science ministry that decides research orientations. They should leave it to the scientists to decide for themselves what the most important scientific opportunities are. Scientific progress cannot be made by decree.

In addition, instead of simplifying the structure of the research system, the government has multiplied new structures. We have hubs of competitiveness, thematic hubs and thematic networks. The list goes on. A single lab might be attached to four different hubs, all linked to others. Each of these structures has its own boards, meetings, statutes, funds, and requests for grant proposals. Just to get their job done, researchers have to juggle new layers of bureaucracy and all sorts of different calls for proposals.

French science does have serious difficulties, and there is worse to come, because the negative impact of recent government policies will take time to show.

\section{Soumitra Dutta}

Chair of business and technology at the European campus of INSEAD, a top business school in Fontainebleau, near Paris.

One should not underestimate France's strength in research and innovation. Innovation is much more complex than scores on this or that indicator. There are many factors that contribute to innovation, from infrastructure to human capacity, the ability to bring research to the market, and the complexity of doing business in a country.
At INSEAD this year we created a Global Innovation Index that combines more than 80 formal indicators on innovation, as well as informal surveys of the opinions of chief executives worldwide. France ranks fifth in the index, with the United States leading, followed by Germany, Britain and Japan.

France's strength lies in large technologybased companies in many sectors. It has been less successful in spawning new high-technology businesses, such as information technology. It also suffers from complexity in doing business, and inflexibility in its labour markets makes adapting to change difficult. Its lack of top research universities and the poor quality of tertiary education are weaknesses. Globalization means that success in innovation is now highly dependent on attracting top talent, and France isn't succeeding in this area.

France needs to realize that success in innovation also depends on factors outside France. Foreign talent is a critical factor, and no country can succeed without it, but talent is now globally mobile. If a country doesn't have the best universities it won't get the best students, and it won't have the best universities unless it can attract the best researchers.

An open attitude towards skilled immigration is also key, and this is going to be a massive problem for France's future. It ranks 61st in the world in terms of reducing obstacles to skilled foreign labour; Britain is 12 th, a factor that largely explains its economic boom. Measures such as automatic work permits for skilled staff are a magnet for talent.

Immigration is such a politically charged issue in France that policies relating to it are a mess. France needs to be more open to skilled immigration, and needs to learn how to make foreigners feel at home - a key factor in the high-tech success of the United States. 